\title{
$W^{\prime=1 \pi}$ \\ https://doi.org/10.52696/IWLM6113 \\ Reprints and permission: \\ The Malaysian English Language Teaching Association \\ Corresponding Author: \\ Noraini Abd Samad p96120@siswa.ukm.edu.my
}

\section{Formative Assessment: Master Trainers' Attitude and Practice}

\author{
Noraini Abd Samad \\ Centre of Education Leadership and Policy, Faculty of Education \\ Universiti Kebangsaan Malaysia, Bangi, Malaysia \\ Zolkepeli Haron \\ Centre of Education Leadership and Policy, Faculty of Education \\ Universiti Kebangsaan Malaysia, Bangi, Malaysia
}

\begin{abstract}
Formative Assessment (FA) as discussed by Black and Wiliam (1998) was introduced to English teachers in 2018 through English Language Education Reform which aligns the curriculum, teaching and learning, and assessment to the Common European Framework of Reference (CEFR). A group of teachers were handpicked by the Ministry of Education (MOE) to undergo a centralized training regarding FA with Cambridge Assessment in English Language Training Centre (ELTC). These teachers were then appointed as Master Trainers (MT) and were tasked to train teachers all over the country. However, two years after the introduction, little application of the assessment can be seen in schools. Hence, the research focusses on the MTs to see whether they themselves possess good attitude towards the assessment and practise the principles of assessment. Data was collected from 40 MTs all over Malaysia through a questionnaire which was distributed online. Overall, data from the questionnaire have revealed that the participants have positive attitudes towards FA and the assessment is an establishing practice in their classroom. Even though there is a positive correlation between attitude and practice, attitude is found to play a small role. Therefore, more support should be provided by MOE to teachers as to ensure assessment for learning is practised widely by English teachers in the nation.
\end{abstract}

\section{KEYWORDS: formative assessment, assessment for learning, teachers' attitude, teachers' practice, English teaching and learning}




\section{Introduction}

Reforms in the education mostly revolve around what should be taught, how should it be learned and how should learning be assessed (Popham, 2011). These questions are valid and important to be explored to ensure that we are providing the best teaching and learning experience to our learners. Of late, assessment, be it summative or formative have received more attention given their role in supporting learning (Black \& Wiliam, 2006).

Unlike summative assessment (SA) which is usually done after a learning session to evaluate the overall progress and its effectiveness, formative assessment (FA) could be done throughout the learning with the purpose of collecting information regarding learning progress which will be used to decide the next step in learning (Cambridge Assessment, 2018). The use of assessment input for learning progress is what makes FA be seen as the bridge between teaching and learning. This bridge is proven as an important component in increasing learners' achievement and is able to inculcate interest in lifelong learning (Young \& Jackman, 2014). Moreover, reviews by Crooks (1988), Black and Wiliam (1998), Nyquist (2003) and Bennett (2011) proved that FA could multiply learning momentum if it is done accurately.

The difference between SA and FA is not limited to when and why they are carried out. FA involves five important elements which requires teachers to possess specific skills such as questioning techniques and the ability to translate learning objectives into success criteria (Black \& Wiliam, 2009). However, the most important skill that teachers need to acquire in order to implement FA effectively is the ability to plan assessments throughout each teaching and learning session. They also need to be able to interpret assessment input to identify learners' needs and progress. Ultimately, teachers need to be able to adapt their teaching according to the assessment input that are collected throughout each lesson (Cambridge Assessment, 2018)

FA as discussed by Black and Wiliam (1998a) was introduced to English teachers in Malaysia in 2018 through English Language Education Reform 2015-2025 which aligns the curriculum, teaching and learning, and assessment to Common European Framework Of Reference (CEFR) (ELSQ Council, 2015). More than 200 teachers were selected to undergo a training where they were exposed to formative assessment theories and principles. This group of teachers were appointed as Master Trainers (MT) and were responsible to disseminate the information to other teachers around the country through a series of cascade training (Aziz, Rashid, \& Zainudin, 2018). FA is core to the CEFR-aligned curriculum and therefore, English teachers are encouraged to practise the assessment as it has been proven to increase learners' motivation and achievement (Cauley \& McMillan, 2010)

Although every reform, policy and innovation seek to better the education world, negligence towards factors and conceptions that influence teachers' practice may affect the change intended making it less impactful and ineffective (Hargreaves \& Fullan, 1998; Robinson \& Walker, 1999). This is especially true with top-down initiatives which are heavily influenced by teachers' level of co-operation, knowledge and belief (Brown, Hui, Yu, \& Kennedy, 2011). The introduction of FA in English teaching and learning is one of top-down initiative. Hence, it is imperative to understand teachers' attitude towards the assessment given the fact that the assessment requires them to have 
a set of specific skills. Moreover, it is also important to see how their attitude influence their FA practice.

Therefore, this study is seeking MTs' attitude towards FA, their level of practice and the relationship between the two variables. Following the above, the study looks into the following research questions:

a) What is the attitude of MTs towards FA?

b) What is the level of FA practice among MTs?

c) How much influence does the MTs' attitude have over their practice?

\section{Literature Review}

Black and Wiliam (1998b) defined FA as a set of activities carried out by teachers and/or learners to collect evidence of learning which will be used to modify teaching and learning activities based on learners' needs. It will also be used to guide teachers in giving feedback to learners to help move their learning forward (Wiliam, 2018). FA focusses heavily on the learning process and it is usually done throughout the lesson whether from minute to minute or day to day (Thompson $\&$ Goe, 2009).

Wiliam (2018) stressed that modification of learning based on assessment input is the core of FA. He also outlined five principles of FA that can help teachers collect their learners' evidence of learning which is crucial in guiding any modification of learning.

1. Sharing and understanding learning objectives and success criteria.

2. Helping learners to show what they learned (e.g. in classroom discussion).

3. Giving feedback that moves learning forward.

4. Helping learners to help and support each other with their learning.

5. Helping learners to be owners of their learning.

The principles above show that FA through its sociocultural background approach helps in identifying learning gaps, reinforcing new learning and anticipating the next step in learning (Bennett \& Gitomer, 2009). FA also encourages learners to self-regulate their learning (Andrade, 2010; Andrade \& Heritage, 2018).

Empirical studies regarding FA done in many countries (e.g. United Kingdom, Canada, Hong Kong, Singapore) across various level of education (from pre-school until tertiary level) and subjects (Mathematics, Language, Science) found positive impact of FA on learning especially in increasing academic achievement, motivation and learners' involvement in teaching and learning session (Bennett, 2011; Black \& Wiliam, 2009; Dunn \& Mulvenon, 2009; Filsecker \& Kerres, 2012; Hattie \& Timperley, 2007; Kingston \& Nash, 2011)

Kingston and Nash (2011) have found practising FA in an English class helped with learners' language skill. In addition, Volante and Beckett (2011) summarised that learning pace can be multiplied through the use of FA strategies such as effective questioning techniques, nongraded feedback, self-assessment, peer assessment and the use of SA formatively. FA was also found to 
help low achievers tremendously which in the end reduced the learning gaps among learners in a class (Black \& Wiliam, 1998b)

Despite all the benefits that FA could offer, it would not be successful if teachers have an unfavourable attitude towards assessment. Academicians have concluded that attitude, perception and belief are sub-groups to constructs which shaped, defined and explained mental conditions and they have an influence to individual's behaviour (Ahmedi, 2019). Attitudes, in particular, have been identified as important factor in determining teachers' behaviour in various aspect of curriculum or co-curricular. Oreck (2004) has found that teachers' attitude played a part in encouraging learners' participation in an art class while Maier, Greenfield, and Bulotsky-Shearer (2013) have found the same in a science class. Kale and Goh (2014) have also found that teachers' attitude was a vital factor for the success of technology adoption in a classroom.

In extension, Brown (2004) has insisted that studies on teachers' opinion, attitude and belief towards assessment is crucial as there are many research findings which stated that teachers' opinion, attitude and belief towards teaching, learning and curriculum have a strong influence over their practice and ultimately their learning output. The necessity of such study is more pivotal when it involves new policies to guarantee not only the success of those policies but to also gain insights which would then be used for the development of teachers' education (Brown et al., 2011).

An insight to teachers' attitude towards FA would be helpful as the assessment is challenging where teachers have to choose wisely on which assessment practice suits their teaching and integrate it in their pedagogy (Blatchford, Baines, Rubie-Davies, Bassett, \& Chowne, 2006; Leahy, Lyon, Thompson, \& Wiliam, 2005). Moreover, teaching is considered very personal where teachers develop their own philosophy while trying to make sense of the curriculum and assessment (Harrison, 2013). Therefore, it is clear that attitude and cognitive factors may have an effect on teachers' teaching and assessment practise.

Results from a study based on Theory Of Planned Behaviour by Yan and Cheng (2015) showed instrumental attitude was a significant predictor of teachers' intention to conduct FA. A positive attitude was also identified as a key factor to positive implementation of FA and vice versa (Hajah Norwati, Mohd Isa, Ab Halim, \& Mohd Aliff (2016); Pastore, Manuti, \& Scardigno (2019). These findings however are in disagreement with Black and Wiliam (2018) who think teachers' assessment practise may not always mirror their belief and attitude. This is the case found in Young and Jackman (2014) study. Johnson, Sondergeld, and Walton (2019) discovered the same especially when it comes to certain FA strategies. Alkharusi, Kazem, and Al-Musawai (2011) and Yamtim and Wongwanich (2014) explained that this is due to teachers' belief that they are incompetent. Hence, teachers chose to only apply strategies that they are comfortable with.

This variability of findings shows that teachers' attitude regarding FA is unique to a demography. Therefore, it is important to study Malaysia's teachers' attitude about the assessment, their practice and the relationship between the two so that suitable actions could be taken to ensure that the introduction of FA in English classroom in the country does not go to waste. 


\section{Method}

This research employs a quantitative approach to obtain data concerning MTs' attitude towards FA and their practise.

\section{Participants}

The population of the study is a group of English teachers who were appointed as MTs for FA under the English Language Education Reform 2015-2025 initiative. Purposive sampling was employed by emailing 60 of these MTs to invite them to join the study where 40 of them agreed. Mohd Majid Konting (2009) mentioned that 40 samples is enough for any research to be carried out and to run inferential statistic if the data collected abide to normality assumptions (Fraenkel, Wallen, \& Hyun, 2012). 12 of the respondents are male and 28 are female. $45 \%$ of them are secondary school teachers while the rest are from primary schools.

\section{The Instrument}

The questionnaire used in this study is adapted from Neesom (2000), Yan and Cheng (2015), and Young and Jackman (2014) for the first construct which aimed to measure MTs' attitude towards FA. Meanwhile the second construct was adapted from O'Leary, Lysaght, dan Ludlow (2017). This construct is to measure MTs' FA level of practice. 9 new items were developed for the first construct and 13 for the second one based on Teacher Handbook of Formative Principles and Practices (Cambridge Assessment, 2018). This handbook was distributed to all schools in Malaysia for English teachers' perusal.

The first construct "Attitude Towards FA" consists of 17 items. 5 points Likert Scale was employed for this construct with labels: Strongly Disagree (1), Disagree (2), Somewhat Agree (3), Agree (4) and Strongly Agree (5). The second construct "FA Practice" consists of 21 items and uses 5 points scale with different labels which are Never (1), Sporadic (2), Emerging (3), Established (4) and Embedded (5).

All items in the questionnaire had undergone face validity and content validity process using Content Validity Ratio (Lawshe, 1975). This procedure involved ten panel of experts which included lecturers from public universities, lecturers from ELTC and SISC+. Items which did not achieved experts' agreement ratio were dropped and the remaining items were further rectified based on panel of experts' opinion.

The questionnaire was then administered to 30 MTs as a pilot study to identify its internal consistency. These 30 MTs were not from the sample pool. Johnson and Christenen (2014) and Muijs (2012) stated a Cronbach's Alpha of 0.70 is accepted as an indicator of a good internal consistency. Analysis of pilot study showed the Cronbach's Alpha for construct one and two are 0.874 and 0.890 . This proved that all items are fit to be used in the real study. 


\section{Collecting Responses}

The data was collected via an online questionnaire (Google Form), which was emailed to every MT who agreed to participate in the study. A brief introduction of the study was provided so the MTs were aware of its purpose and objectives. Administering the questionnaire online increased accessibility as these MTs are all over the country making logistics difficult.

All MTs were given two weeks to respond to the questionnaire and to return it to the researcher via email. Throughout that period, assistance and clarification were given if required. After two weeks, data obtained was statistically analysed using IBM SPSS Statistics Version 23.

\section{Results}

\section{Master Trainers'Attitude Towards Formative Assessment}

To interpret the min score of the first construct, the study referred to Nunnally and Bernstein (1994) interpretation of min score as detailed in Table 1.

Table 1. Min Score Interpretation

\begin{tabular}{cc}
\hline Min Score & Interpretation \\
\hline $4.01-5.00$ & High \\
$3.01-4.00$ & Medium High \\
$2.01-3.00$ & Medium Low \\
$1.00-2.00$ & Low \\
\hline
\end{tabular}

Overall, MTs' attitude towards FA is at a medium high level with construct min score 3.91 (SD = 0.50). MTs' individual score is then grouped into five categories according to their score range. It shows that more than half of the MTs have positive attitude towards the assessment. This grouping is showed in Table 2 below.

Table 2. MTs Attitude towards Formative Assessment

\begin{tabular}{|c|c|c|c|c|c|}
\hline Construct & $\begin{array}{c}\text { Completely } \\
\text { Negative }\end{array}$ & $\begin{array}{c}\text { Partially } \\
\text { Negative }\end{array}$ & $\begin{array}{c}\text { Somewhat } \\
\text { Positive }\end{array}$ & Positive & $\begin{array}{c}\text { Completely } \\
\text { Positive }\end{array}$ \\
\hline Attitude & $0 \%$ & $2.5 \%$ & $25 \%$ & $65 \%$ & $7.5 \%$ \\
\hline
\end{tabular}

Analysis on agreement rate for every item showed that not all MTs possess good attitude towards several formative assessment strategies. Items related to feedback received discouraging rate which reflected MTs less favourable attitude towards the strategy. Table 3 details this finding. 
Table 3. MTs Agreement Rate on Certain Items

\begin{tabular}{|l|c|c|c|c|c|c|}
\hline \multicolumn{1}{|c|}{ Statements } & $\begin{array}{c}\text { Strongly } \\
\text { Agree }\end{array}$ & Agree & $\begin{array}{c}\text { Somewhat } \\
\text { Agree }\end{array}$ & $\begin{array}{c}\text { Disagree } \\
\text { Disagree }\end{array}$ & $\begin{array}{c}\text { Strongly } \\
\text { (mean, } \\
\text { sd) }\end{array}$ \\
\hline $\begin{array}{l}\text { I do not believe plenary } \\
\text { activities could help my } \\
\text { pupils consolidate their } \\
\text { learning }\end{array}$ & 47.5 & 22.5 & 17.5 & 12.5 & 0.0 & 4.05 \\
\hline $\begin{array}{l}\text { I find the concept of } \\
\text { deliberate practice is } \\
\text { difficult to apply }\end{array}$ & 25.0 & 35.0 & 22.5 & 15.0 & 2.5 & 3.65 \\
\hline $\begin{array}{l}\text { Identifying ways to help } \\
\text { my pupils move forward in } \\
\text { their learning is tedious }\end{array}$ & 22.5 & 17.5 & 42.5 & 15.0 & 2.5 & 3.43 \\
\hline $\begin{array}{l}\text { Individualised non-graded } \\
\text { feedback is impossible to } \\
\text { do }\end{array}$ & 10.0 & 40.0 & 35.0 & 10.0 & 5.0 & 3.40 \\
\hline $\begin{array}{l}\text { I do not have enough time } \\
\text { to check on my pupils' } \\
\text { action towards feed } \\
\text { forward }\end{array}$ & 2.5 & 17.5 & 50.0 & 22.5 & 7.5 & 2.85 \\
\hline
\end{tabular}

Master Trainers' Practice of Formative Assessment

Lysaght, O'Leary and Ludlow (2017) have divided respondents to their questionnaire into four categories based on their score range which are detailed in Table 4. The analysis shows that 37 MTs fall under Established category while 3 of them are under Embedded.

Table 4. Interpretation for MTs Practice

\begin{tabular}{|c|c|}
\hline Score Range & Interpretation \\
\hline 78 and above & Embedded \\
\hline $61-77$ & Established \\
\hline $44-60$ & Emerging \\
\hline $0-43$ & Sporadic \\
\hline
\end{tabular}

Teachers under Established are described as someone with high FA skills and is using practices which are relatively hard to embed. FA is a growing feature of pedagogy and as such it is an approach with which the teacher and pupils are beginning to engage more fully. They use a fuller range of techniques including all aspects related to sharing learning objectives and success criteria. Teachers in the category also practise aspects related to effective feedback, sharing questioning role with their pupils and starting to introduce one or two aspects of self- and peer-assessment.

Meanwhile, teachers under Embedded are described as someone with very high FA skills and is using practices which are very hard to embed. Formative assessment is likely to be a customary or 
firmly established feature of pedagogy and occurs routinely in day-to-day teaching and learning. Teachers in this category employ the full range of practices and their practice is distinguished by their incorporation of four additional techniques associated with self- and peer-assessment.

Analysis on level of practise for every item showed that there are some FA strategies which are not widely practised by these MTs. These strategies are related to differentiated learning, effective feedback and peer- and self-assessment. Table 5 provides details of each strategy.

Table 5. Relationship between Attitude and Practice of Formative Assessment

\begin{tabular}{|c|c|c|c|c|c|c|}
\hline Strategy & Never & Sporadic & Emerging & Established & Embedded & $\begin{array}{l}\text { Summary } \\
\text { (mean,sd) }\end{array}$ \\
\hline $\begin{array}{l}\text { Success criteria related } \\
\text { to learning objectives } \\
\text { are differentiated and } \\
\text { shared with pupils }\end{array}$ & 2.5 & 12.5 & 30.0 & 42.5 & 12.5 & $\begin{array}{c}4.50 \\
0.961\end{array}$ \\
\hline $\begin{array}{l}\text { Feedback to pupils is } \\
\text { focussed on the original } \\
\text { learning objective and } \\
\text { success criteria }\end{array}$ & 2.5 & 7.5 & 37.5 & 40.0 & 12.5 & $\begin{array}{c}4.53 \\
0.905\end{array}$ \\
\hline $\begin{array}{l}\text { Feedback is turned into } \\
\text { targets for pupils to } \\
\text { work on autonomously }\end{array}$ & 2.5 & 12.5 & 30.0 & 45.0 & 10.0 & $\begin{array}{c}4.48 \\
0.933\end{array}$ \\
\hline $\begin{array}{l}\text { Feedback is specially } \\
\text { catered to individual }\end{array}$ & 0 & 15.0 & 40.0 & 35.0 & 10.0 & $\begin{array}{c}4.40 \\
0.871 \\
\end{array}$ \\
\hline $\begin{array}{l}\text { Pupils are encouraged to } \\
\text { use a range of } \\
\text { assessment techniques } \\
\text { to review their friends' } \\
\text { work }\end{array}$ & 7.5 & 7.5 & 47.5 & 32.5 & 5.0 & $\begin{array}{c}4.20 \\
0.939\end{array}$ \\
\hline $\begin{array}{l}\text { A visual record of } \\
\text { pupils' progress is } \\
\text { maintained to celebrate } \\
\text { pupils learning and } \\
\text { show areas of/for } \\
\text { development }\end{array}$ & 10 & 22.5 & 35.0 & 30.0 & 2.5 & $\begin{array}{c}3.93 \\
1.023\end{array}$ \\
\hline $\begin{array}{l}\text { Pupils are encouraged to } \\
\text { review their own } \\
\text { learning approach as one } \\
\text { way to achieve their } \\
\text { learning target }\end{array}$ & 0 & 22.5 & 50.0 & 25.0 & 2.5 & $\begin{array}{c}4.08 \\
0.764\end{array}$ \\
\hline $\begin{array}{l}\text { Pupils are welcomed to } \\
\text { prepare their own short } \\
\text { test to assess their } \\
\text { friends' learning }\end{array}$ & 22.5 & 30.0 & 30.0 & 12.5 & 5.0 & $\begin{array}{c}3.48 \\
1.132\end{array}$ \\
\hline
\end{tabular}


Pearson Correlation analysis was carried out to determine the relationship between attitude towards FA and the practice of it in MTs daily teaching. Finding shows that there is a positive linear correlation with $r$ value $=0.576, n=40$ and $p<0.001$. The $r$ value is interpreted as strong by Field (2018) which means the more positive the attitude towards FA, the more likely these MTs will practise it. Nonetheless, analysis done on covariance shows only $33.2 \%$ of attitude score contributes directly to the practice of FA. This means there are other factors which were not measured in this study that contributes to the practice of FA in MTs' classroom.

\section{Discussion}

The findings of this study are important to the build-up of FA literature in Malaysia taking into account that fact that these MTs were the first group of English teachers in the country exposed to the theories and principles of FA. Overall, MTs attitude towards FA is at medium towards high level based on the min score. $72.5 \%$ of them are in the positive categories. Nevertheless, there are MTs in the somewhat positive and partially negative categories which is a concern. This shows that even though they received a direct and in-depth exposure to FA, it did not totally guarantee a positive attitude. Given that this study did not explore factors behind MTs' attitude, no concrete explanation could be provided. In support of this finding, Volante and Beckett (2011) have suggested that teachers may develop negative attitude towards FA due to certain blocks related to strategies such as peer- and self-assessment. This is reflected in this study findings as items related to these two strategies were found to receive the lowest agreement rate from respondents. Apart from peer- and self-assessment, items reflecting effective feedback and deliberate practice also received low agreement rate.

Based on MTs' attitude score, it is expected that their practice to be at a high level and this is reflected through this study's findings. For the majority of these MTs, FA happens $75 \%$ of the time while some MTs practise it $90 \%$ of the time. However, there are strategies such as differentiated learning, addressing learning gap, effective feedback and peer- and self-assessment which were not practised enough by the respondents. These strategies have been identified as difficult and may be one of the reasons behind the lack of use of FA (Johnson et al., 2019; Lysaght \& O'Leary, 2013; Pastore et al., 2019). This difficulty causes teachers to view FA as an added burden instead of seeing it as one of important elements in their teaching (Coffey, Hammer, Levin, \& Grant, 2011). Young dan Jackman (2014) suggested that when teachers see that practising FA strategies requires extra effort in terms of time and resources, they will avoid those specific strategies even if they think it will be worthwhile.

This study also found a strong, positive correlation between attitude towards FA and its practice. However, as reported earlier, the influence is not huge. This indicate that there may be some factors that could affect FA practice. Parr and Timperley (2008) linked these factors to school organisational culture, teachers' readiness and limited sources. Volante, Beckett, Reid, and Drake (2010) on the other hand, listed lack of training, resistance from parents and pupils, and lack of instructional leadership as factors influencing FA practice. They concluded that these factors will definitely impact teachers' practise of FA despite their good level of knowledge, perception and attitude towards the assessment. 
The findings of this study proved that professional training regarding FA yielded positive attitude. Positive attitude which then translated to its application in the classroom. However, the findings also showed that this attitude did not apply to all FA strategies. This shows that one-off training like the one provided by MOE is not adequate. It is clear that teachers need continuous in-service training and support in order for them to be adept in implementing FA effectively (Desimone, 2009; Furtak et al., 2016; C. C. Johnson et al., 2019; Yan \& Cheng, 2015). Therefore, authorities need to take the appropriate initiative to ensure the newly introduced assessment will not get drowned by teachers' confusion. This is also to make sure the investment made by MOE will not go to waste as the training involved foreign consultants from Cambridge Assessment.

\section{Limitation of The Study}

The findings of this study are limited to its respondents and they cannot be generalised to English teachers' population due to the difference in training received by the two. Other than that, there is the concern about the reliability of self-reported data as there are chances that respondents are not truthful especially when reporting their practice (Lysaght \& O'Leary, 2013). This may due to concerns about people's perception towards them as an MT. Hence, triangulation via observation is recommended to support respondents' responses. Nonetheless, information gained through this study still provides a foundation to explore FA in Malaysia.

\section{Conclusion}

FA is introduced to English teachers in Malaysia with the aim to enhance the quality of teaching and learning across all levels. To guarantee that this could be achieved, teachers must be given ample knowledge so that they have positive attitude towards the assessment. However, as discussed above, knowledge and attitude alone are not enough. Teachers are bound to meet hiccups along the way as they implement the assessment especially when it comes to certain specific strategies. Hence, support in terms of workshop, professional learning community or support group must be provided so teachers can direct their questions or problems related to the assessment. With enough support, it is without a doubt that teachers will continue to use FA in their teaching and ultimately move away from the traditional practice of teaching for examination.

For further study of FA in Malaysia, the scope of this study could be widened to include English teachers from both secondary and primary school to see the difference in attitude and practice between teachers and MTs. This is to see whether level of training has any effect on the two variables. Plus, there is also a need to better understand external factors affecting the implementation of FA in English classroom nationwide

\section{References}

Ahmedi, V. (2019). Teachers' Attitudes And Practices Towards Formative Assessment In Primary Schools. Journal of Social Studies Education Research, 10(3), 161-175.

Alkharusi, H., Kazem, A. M., \& Al-Musawai, A. (2011). Knowledge, Skills, And Attitudes Of Preservice And Inservice Teachers In Educational Measurement. Asia-Pacific Journal of Teacher Education, 39(2), 113-123. https://doi.org/10.1080/1359866X.2011.560649 
Andrade, H. (2010). Handbook of Formative Assessment. In Handbook of Formative Assessment. https://doi.org/10.4324/9780203874851

Andrade, H. L., \& Heritage, M. (2018). Using Formative Assessment to Enhance Learning, Achievement, and Academic Self-Regulation. https://doi.org/10.4324/9781315623856

Aziz, A. H. A. A., Rashid, R. A., \& Zainudin, W. Z. W. (2018). The Enactment Of The Malaysian Common European Framework Of Reference (CEFR): National Master Trainer's Reflection. Indonesian Journal of Applied Linguistics, 8(2), 409-417. https://doi.org/10.17509/ijal.v8i2.13307

Bennett, R. E. (2011). Formative Assessment: A Critical Review. Assessment in Education: Principles, Policy and Practice, 18(1), 5-25. https://doi.org/10.1080/0969594X.2010.513678

Bennett, R. E., \& Gitomer, D. H. (2009). Transforming K-12 Assessment: Integrating Accountability Testing, Formative Assessment and Professional Support. Educational Assessment in the 21st Century: Connecting Theory and Practice, (July), 43-61. https://doi.org/10.1007/978-1-4020-9964-9_3

Black, P., \& Wiliam, D. (1998a). Assessment And Classroom Learning. International Journal of Phytoremediation, 21(1), 7-74. https://doi.org/10.1080/0969595980050102

Black, P., \& Wiliam, D. (1998b). Inside The Black Box: Raising Standards Through Classroom Assessment. Phi Delta Kappan, 80(2), 139-144, 146-148. https://doi.org/10.1177/003172171009200119

Black, P., \& Wiliam, D. (2006). Assessment For Learning In The Classroom. In J. Gardner (Ed.), Assessment and Learning (pp. 9-26). https://doi.org/10.4135/9781446250808.n2

Black, P., \& Wiliam, D. (2009). Developing The Theory of Formative Assessment. Educational Assessment, Evaluation and Accountability, 21(1), 5-31. https://doi.org/10.1007/s11092008-9068-5

Black, P., \& Wiliam, D. (2018). Classroom Assessment and Pedagogy. Assessment in Education: Principles, Policy and Practice, 25(6), 551-575. https://doi.org/10.1080/0969594X.2018.1441807

Blatchford, P., Baines, E., Rubie-Davies, C., Bassett, P., \& Chowne, A. (2006). The Effect Of A New Approach To Group Work On Pupil-Pupil and Teacher-Pupil Interactions. Journal of Educational Psychology, 98(4), 750-765. https://doi.org/10.1037/0022-0663.98.4.750

Brown, G. T. L. (2004). Teachers' Conceptions Of Assessment: Implications For Policy And Professional Development. Assessment in Education: Principles, Policy and Practice, 11(3), 301-318. https://doi.org/10.1080/0969594042000304609

Brown, G. T. L., Hui, S. K. F., Yu, F. W. M., \& Kennedy, K. J. (2011). Teachers' Conceptions Of Assessment In Chinese Contexts: A Tripartite Model Of Accountability, Improvement, and Irrelevance. International Journal of Educational Research, 50(5-6), 307-320. https://doi.org/10.1016/j.ijer.2011.10.003

Cambridge Assessment. (2018). Teacher Handbook Formative Assessment Principles and Practices. Kuala Lumpur: Kementerian Pendidikan Malaysia.

Cauley, K. M., \& McMillan, J. H. (2010). Formative Assessment Techniques to Support Student Motivation and Achievement. The Clearing House: A Journal of Educational Strategies, Issues and Ideas, 83(1), 1-6. https://doi.org/10.1080/00098650903267784

Coffey, J. E., Hammer, D., Levin, D. M., \& Grant, T. (2011). The Missing Disciplinary Substance Of Formative Assessment. Journal of Research in Science Teaching, 48(10), 1109-1136. https://doi.org/10.1002/tea.20440

Council, E. L. S. and Q. (2015). English Language Education Reform in Malaysia: The Roadmap 2015 -2025. Ministry of Education, Malaysia, 39(5), 561-563. Retrieved from http://eltc.moe.edu.my/roadmap/The Roadmap 2015-2025.pdf

Crooks, T. J. (1988). The Impact of Classroom Evaluation Practices on Students. In Review of Educational Research (Vol. 58). https://doi.org/10.3102/00346543058004438

Desimone, L. M. (2009). Improving Impact Studies Of Teachers' Professional Development: Toward Better Conceptualizations And Measures. Educational Researcher, 38(3), 181-199. https://doi.org/10.3102/0013189X08331140 
Dunn, K. E., \& Mulvenon, S. W. (2009). A Critical Review of Research on Formative Assessment: The Limited Scientific Evidence of the Impact of Formative Assessment in Education. Practical Assessment, Research \& Evaluation, 14(7), 1-19. https://doi.org/10.1002/ir

Field, A. (2018). Discovering Statistics Using IBM SPSS Statistics (5th ed.). London: SAGE Publication Ltd.

Filsecker, M., \& Kerres, M. (2012). Repositioning Formative Assessment From An Educational Assessment Perspective: A Response To Dunn \& Mulvenon (2009). Practical Assessment, Research and Evaluation, 17(16), 1-9.

Fraenkel, J. R., Wallen, N. E., \& Hyun, H. H. (2012). How to Design and Evaluate Research in Education, 8th Edition (2012) (8th ed.). New York: Mc Graw Hill Humanities.

Furtak, E. M., Kiemer, K., Circi, R. K., Swanson, R., de León, V., Morrison, D., \& Heredia, S. C. (2016). Teachers' Formative Assessment Abilities And Their Relationship To Student Learning: Findings From A Four-Year Intervention Study. Instructional Science, 44(3), 267-291. https://doi.org/10.1007/s11251-016-9371-3

Hajah Norwati, H. A. B., Mohd Isa, H., Ab Halim, T., \& Mohd Aliff, M. N. (2016). Pandangan Guru Pendidikan Islam terhadap "Sbafl” di Sekolah Menengah di Negara Brunei Darussalam. Jurnal Sultan Alauddin Sulaiman Shah, 3(2), 19-31.

Hargreaves, A., \& Fullan, M. (1998). What's Worth Fighting for Out There? New York: Teachers' College Press.

Harrison, C. (2013). Collaborative Action Research As A Tool For Generating Formative Feedback On Teachers Classroom Assessment Practice: The KREST project. Teachers and Teaching: Theory and Practice, 19(2), 209-220. https://doi.org/10.1080/13540602.2013.741839

Hattie, J., \& Timperley, H. (2007). The Power Of Feedback. Review of Educational Research, 77(1), 81-112. https://doi.org/10.3102/003465430298487

Johnson, C. C., Sondergeld, T. A., \& Walton, J. B. (2019). A Study of the Implementation of Formative Assessment in Three Large Urban Districts. In American Educational Research Journal. https://doi.org/10.3102/0002831219842347

Johnson, R. B., \& Christenen, L. (2014). Educational Research :Quantitative, Qualitative, and Mixed Methods Approaches (4th ed.). Alabama: Sage Publication Inc.

Kale, U., \& Goh, D. (2014). Teaching Style, ICT Experience And Teachers' Attitudes Toward Teaching With Web 2.0. Education and Information Technologies, 19(1), 41-60. https://doi.org/10.1007/s10639-012-9210-3

Kingston, N., \& Nash, B. (2011). Formative Assessment: A Meta-Analysis And A Call For Research. Educational Measurement: Issues and Practice, 30(4), 28-37. https://doi.org/10.1111/j.1745-3992.2011.00220.x

Lawshe, C. . (1975). A Quantitative Approach To Content Validity. Personnel Psychology, 28, 561-580.

Leahy, S., Lyon, C., Thompson, M., \& Wiliam, D. (2005). Classroom Assessment: Minute By Minute, Day By Day. Educational Leadership, 63(3), 19-24.

Lysaght, Z., \& O'Leary, M. (2013). An Instrument To Audit Teachers' Use of Assessment for Learning. Irish Educational Studies, 32(2), 217-232. https://doi.org/10.1080/03323315.2013.784636

Maier, M. F., Greenfield, D. B., \& Bulotsky-Shearer, R. J. (2013). Development And Validation Of A Preschool Teachers' Attitudes And Beliefs Toward Science Teaching Questionnaire. Early Childhood Research Quarterly, 28(2), 366-378. https://doi.org/10.1016/j.ecresq.2012.09.003

Mohd Majid Konting. (2009). Kaedah Penyelidikan dalam Pendidikan. In Kaedah Penyelidikan Pendidikan.

Muijs, D. (2012). Doing Quantitative Research in Education with SPSS. In Doing Quantitative Research in Education with SPSS (2nd ed.). https://doi.org/10.4135/9781849209014

Neesom, A. (2000). Teachers use Assessment For Learning To Raise Standards. London.

Nunnally, J. C., \& Bernstein, I. H. (1994). Psychometric Theory (3rd ed.). New York: Mc Graw 
Hill.

Nyquist, J. B. (2003). The Benefits of Reconstructing Feedback As A Larger System of Formative Assessment: A Meta-Analysis. Vanderbilt University.

O’Leary, M., Lysaght, Z., \& Ludlow, L. (2017). Measuring Teachers' Assessment for Learning (AfL) Classroom Practices in Elementary Schools. International Journal of Educational Methodology, 3(2), 103-115. https://doi.org/10.12973/ijem.3.2.103

Oreck, B. (2004). The Artistic And Professional Development Of Teachers: A Study Of Teachers' Attitudes Toward And Use Of The Arts In Teaching. Journal of Teacher Education, 55(1), 55-69. https://doi.org/10.1177/0022487103260072

Parr, J. M., \& Timperley, H. S. (2008). Teachers, Schools And Using Evidence: Considerations Of Preparedness. Assessment in Education: Principles, Policy and Practice, 15(1), 57-71. https://doi.org/10.1080/09695940701876151

Pastore, S., Manuti, A., \& Scardigno, A. F. (2019). Formative Assessment and Teaching Practice: The Point of View of Italian Teachers. European Journal of Teacher Education, 42(3), 359-374. https://doi.org/10.1080/02619768.2019.1604668

Popham, W. J. (2011). Assessment Literacy Overlooked: A Teacher Educator's Confession. Teacher Educator, 46(4), 265-273. https://doi.org/10.1080/08878730.2011.605048

Robinson, V. M. J., \& Walker, J. C. (1999). Theoretical Privilege and Researchers' Contribution to Educational Change. In J. S. Gaffney \& B. J. Askew (Eds.), Stirring the Waters: The Influence of Marie Clay (p. . 239-259). Portsmouth: Heinemann.

Thompson, M., \& Goe, L. (2009). Models for Effective and Scalable Teacher Professional Development. ETS Research Report Series, 2009(1), i-35. https://doi.org/10.1002/j.23338504.2009.tb02164.x

Volante, L., \& Beckett, D. (2011). Formative Assessment And The Contemporary Classroom: Synergies And Tensions Between Research And Practice. Canadian Journal of Education, 34(2), 239-255.

Volante, L., Beckett, D., Reid, J., \& Drake, S. (2010). Teachers' Views on Conducting Formative Assessment within Contemporary Classrooms. Annual Meeting Od The American Educational Research Association.

Wiliam, D. (2018). Assessment For Learning: Meeting The Challenge of Implementation. Assessment in Education: Principles, Policy \& Practice, 25(6), 682-685. https://doi.org/10.1080/0969594x.2017.1401526

Yamtim, V., \& Wongwanich, S. (2014). A Study of Classroom Assessment Literacy of Primary School Teachers. Procedia - Social and Behavioral Sciences, 116, 2998-3004. https://doi.org/10.1016/j.sbspro.2014.01.696

Yan, Z., \& Cheng, E. C. K. (2015). Primary Teachers' Attitudes, Intentions and Practices Regarding Formative Assessment. Teaching and Teacher Education, 45, 128-136. https://doi.org/10.1016/j.tate.2014.10.002

Young, J. E. J., \& Jackman, M. G. A. (2014). Formative Assessment in The Grenadian Lower Secondary School: Teachers' Perceptions, Attitudes and Practices. Assessment in Education: Principles, Policy and Practice, 21(4), 398-411. https://doi.org/10.1080/0969594X.2014.919248 